\title{
Actions on Humidifying Catchments of the Rivers and to Counteraction to the Spontaneous Phenomena Caused by Changes of a Climate
}

\author{
Svetlana Vasilievna Budnik \\ The Central Geophysical Observatory It, Boris Sreznevskogo, Kiev, Ukraine
}

Email address:

svetlana_budnik@ukr.net

To cite this article:

Svetlana Vasilievna Budnik. Actions on Humidifying Catchments of the Rivers and to Counteraction to the Spontaneous Phenomena Caused by Changes of a Climate. Hydrology. Vol. 8, No. 1, 2020, pp. 1-6. doi: 10.11648/j.hyd.20200801.11

Received: May 24, 2020; Accepted: June 9, 2020; Published: August 10, 2020

\begin{abstract}
Changes of a climate have generated in territory of Ukraine and other countries of the world many various problems, among them reduction humidifying reservoirs of many rivers is marked also. Existing measures on management of a water management in connection with influence of change of a climate are obviously insufficient, about what is spoken and in some documents WMO. In given work on the basis of the analysis of components of water balance of territory the list of actions on regulation dry up reservoirs of the rivers which has arisen in connection with changes of a climate is spent. For the analysis the atmospheric precipitation measured for the long-term period, evaporation from a surface of ground and water, stocks of productive moisture in ground, a layer of a runoff of water are used. Reduction of a river drain on hydrological to a post Sluch Sarny occurs due to reduction of soil inflow, and, decreases not only a component of a soil feed of the river, but also stocks of water in a soil layer 0-100 see. As the actions adjusting humidifying of territory, are recommended: restoration of marsh files, construction of small dams in the top parts of a hydrographic network beams and hollows, agrarian and wood land improvement. For maintenance of an ecological runoff in the river Dnepr regulation of outflow of water to Black sea system of sluices of available water basins is recommended.
\end{abstract}

Keywords: Water Resources, Water Balance, Moisture in Soil, Actions on Humidifying Catchments

\section{Introduction}

Changes of a climate have generated in territory of Ukraine and the world many various problems, among them reduction of humidifying of catchments of many rivers is marked also. It is expressed in reduction of water in channels of the rivers, as small (Ikva, etc.), and greater (Dnepr), reduction of levels aquifer horizons of subsoil waters, reduction of stocks of a moisture in ground and soil thickness. Alongside with it increase of droughts and floodings of significant territories is observed.

Displays of change of stocks of water on territory even one reservoir are not identical [1]. So, for example, on a catchments of the river Pripyat there are sites as with increase of an annual layer of a runoff of water in a long-term cut, and with downturn while the soil runoff on sites with increase of a runoff of water - decreases, and there where reduction of an annual layer of a runoff of water is observed - increases.
Considering displays of droughts and floodings the choice of actions on regulation of consequences of change of a climate for each territory should be individual and be based on basins a principle.

In the country there are strategy of management by a water management $[2,3]$ in view of the developed branches of economy and interests of water-users on the basis of basins a principle, however diversity of water use and a variety of natural resources do not allow to solve a problem only adjusting water consumption or dump of the used waters in a vein of the river. Among recommended control systems of water resources [2,3] allocate such actions: forecasting of high waters, definition of the reasons of problems with water resources (fences and dumps of water, quality assurance of water, influence of various branches in river pool, the changes of a hydrological mode connected with hydraulic engineering construction, changes of a climate, etc.), Forecasting zones of flooding and forecasting of possible damages from high 
waters, development of operating plans flood protection actions, functioning of a water management during the critical periods of water use, etc. In specified «strategy ...» water resources management is focused on regulation and management in water volumes in channels of the rivers and water basins and at all does not mention water-modular territories, namely water-modular territories are a source of water in channels of the rivers and water basins and in long-term scale water-modular territories adjust speed and volume of water inflow in channels of the rivers.

About insufficiency of existent measures on a management in connection with influence of change of climate talked a water economy some documents of WMO [4], here specified on importance of management by croplands in connection with the necessity of softening of consequences of change of climate and maintenance of water resources, agromeliorations, forest cultivation, renewal of wetlands, are recommended [4].

In general, a fight against floods is lately taken to the quickest taking of flood waters from the river-beds of the rivers and dried flood plain that can be already even built-up, it is consequences of urbanization. Although if to remember history of ancient Egypt that floods were considered the gift of Gods and if a water level in Nile did not rise higher certain mark, talked about quick hunger (there is not an overflow of Nile - there is not filling with moisture of soils, there is not a receipt with water of the self-weighted particles, that served as a good fertilizer for sandy soils - there is not a harvest). Existent land-reclamations somehow compensate runoff of water from pools, but on it the considerable expenses of material resources are required and they do not affect all catchments of the river.

State of water resources in Polesye and in a country on the whole causes an anxiety, both specialists and public [5], therefore very topically to find the most vulnerable constituents of water balance of territory, that in certain case determine reduction of water supplies. The aim of work was an analysis of the folded situation with the supplies of water of catchments of the rivers of Ukrainian Polesye and ground of recommendations on overcoming of consequences of change of climate.

\section{Methods and Materials of Researches}

Among the existent methods of research of moistening of catchments of the rivers most reasonable and provided with materials of supervisions there is a method of water balance. The dynamics of constituents of water balance in time and space, foremost, is determined by the change of climatic constituents, what as atmospheric fallouts and temperature (determines evaporation). Research of modern changes of climate on the examined territory shows a height in time of amount of fallouts and temperature of air [6]. Equalization of water balance for a separate river basin is often presented in a next kind:

$$
\mathrm{X}=\mathrm{Y}+\Pi+\mathrm{E}+\mathrm{T} \pm \Delta \mathrm{W}+\mathrm{U},
$$

where $\mathrm{X}$ - are atmospheric fallouts on the surface of basin; Y - is a superficial flow; $\Pi$ - is an underground flow; $E$ - is unproductive evaporation (from the surface of soil and water); $\mathrm{T}$ - is transpiration by plants, $\Delta \mathrm{W}$ - is a change of moisture in a soil layer, $\mathrm{U}$ - is detention of moisture in lowering of relief.

For the decision of certain tasks of science and practice apply more detailed and more differentiated ideas about the structure of water balance. From plenitude of knowledge about the processes of forming of water balance efficiency and exactness of application of calculation and prognosis methods of the й models used in hydrology and other sciences depend in a great deal [7]. Among the constituents of water balance, except fallouts and evaporation, considerable influence on a river flow in a humid zone renders moistening of surface of catchments [8-10].

As the object of research is taken the catchments of the river Sluch to the city of Sarny (Figure 1), which has a series of observations of the main components of the water balance (atmospheric precipitation, evaporation from the surface of the soil and water surface, water flow, reserves of productive moisture in the soil). The River Sluch is the right tributary of the Goryn River, which flows into the Pripyat River and belongs to the watershed of the River Dnepr and the Black Sea. The catchments area of the river Sluch to Sarny is $13,300 \mathrm{~km}^{2}$, the distance from the source to the sash is $409 \mathrm{~km}$, the average height of the catchments is $230 \mathrm{~m}$, and the forest is $17 \%$. The length of the rows used to analyze observations of water balance components varies (Table 1).

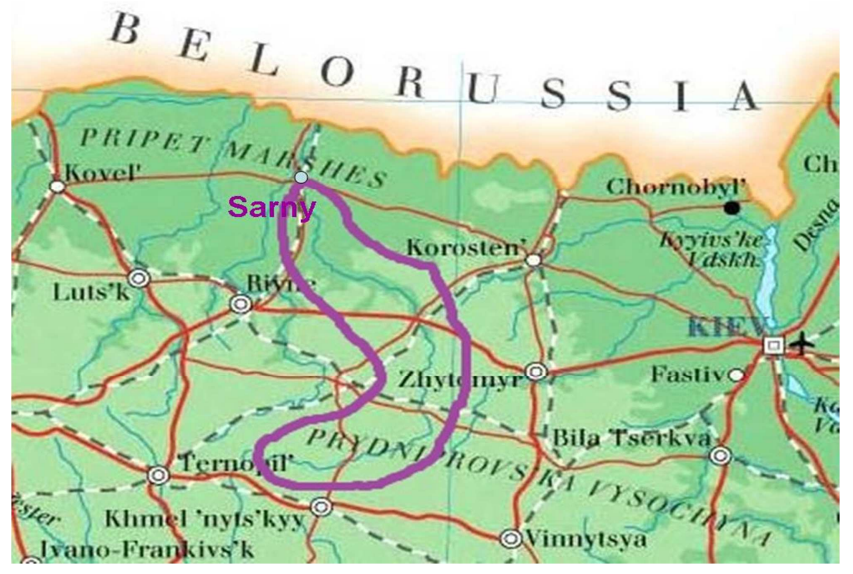

Figure 1. Scheme of the location of the catchments of the river Sluch-Sarny.

\section{Results of Researches}

Studies have been carried out on the relationships of the existing measured components of the water balance (runoff, precipitation, evaporation, reserves of productive moisture in the soil) along the river Sluch - Sarny during the existing period of observations.

Analysis of changes in the time of precipitation, reserves of productive moisture and a depth runoff for the month shows that the peaks of highs of these indicators go consistently with a shift one by one (Figure 2), first maximums of precipitation, then moisture reserves in the soil th the last highs of the dept runoff, which is not contrary to the physics of the process. 
Table 1. Characteristics of the series of observations of water balance components.

\begin{tabular}{|c|c|c|c|}
\hline Water balance component & $\begin{array}{l}\text { Observation } \\
\text { period }\end{array}$ & $\begin{array}{l}\text { Change } \\
\text { range }\end{array}$ & $\begin{array}{l}\text { Average for the period } \\
\text { of observation }\end{array}$ \\
\hline Rainfall for the year, mm, weather station in Sarny & $1911-2016$ & $360-848$ & \multirow{3}{*}{$\begin{array}{l}596 \\
123,4 \\
305,1\end{array}$} \\
\hline Average annual water flow, mm, hydrological post of the River Sluch - Sarny & 1924-2016 & $27-280$ & \\
\hline Evaporation from the surface of the soil, $\mathrm{mm}$, weather station of Sarny & 1959-1990 & $212,8-413,9$ & \\
\hline Evaporation from the water surface, $\mathrm{mm}$, weather station of Sarny & $1958-2017$ & $396-946,4$ & 622,3 \\
\hline $\begin{array}{l}\text { Average for a year reserves of productive moisture in the soil thickness }(0-100 \mathrm{~cm}), \mathrm{mm} \text {, } \\
\text { agrometstation of Sarny }\end{array}$ & 1966-2017 & $83,4-203$ & 128,4 \\
\hline Minimum water runoff for the year, $\mathrm{m}^{3} / \mathrm{s}$, hydrological post of the River Sluch - Sarny & 1924-2016 & $1,16-38$ & 9,79 \\
\hline
\end{tabular}

The evaporation from the soil surface over time corresponds to the course of precipitation. This further explains the less dependence of runoff on precipitation than on the hydration of the surface.

Climate change in the study area is manifested in the increase in average annual air temperature and evaporation, both from the water surface and soil. The amount of precipitation for the year at the Sarny weather station, despite the general upward trend, has a sinusoidal component, which is consistent with the variability of water flow (and medium and minimum) and moisture reserves in the soil layer 0-100 $\mathrm{cm}$ (Figures 3, 4). While in the upper, less powerful layers of soil there is a tendency to reduce moisture reserves over time.

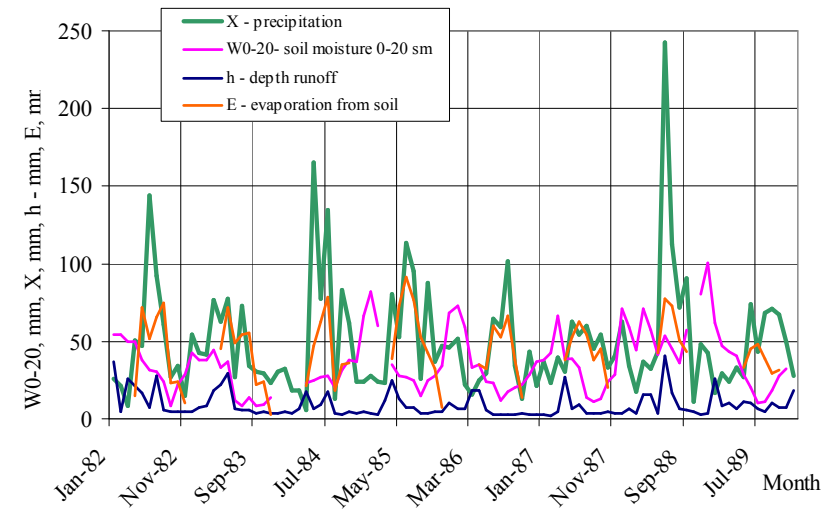

Figure 2. Changes in precipitation time per month, reserves of productive moisture in a layer of 0-20 cm of soil, evaporation from the soil by the Sarny weather station and a depth runoff on the hydrological post of the river Sluch - Sarny.

The maximum precipitation and runoff for the year was observed in 1998, after which there was a decline in their number. The maximum reserves of moisture in the soil are observed in 1988, and the maximum smoothing trend in 1997-99, i.e. due to the inertia of reducing moisture reserves, their number of about 9-10 years lasted at a high level, and then still showed a decline in indicators. The works $[4,13,14]$ based on the analysis of observational materials up to the $90 \mathrm{~s}$ of the 20th century on more than 600 weather stations of the world, including in the USSR, indicate the presence of a long-term trend of moisture content in the upper (up to $1 \mathrm{~m}$ ) layer of soil. And in 2012, from the materials presented by T. Adamenko to the FAO report [15] on soil moisture in a meter layer of soil on May 28, from 1961-2012 under wheat, it is clear that the reserves of moisture in the soil are disappearing. According to the data [16], the drying of soil-ground thickness under the influence of climate change has been traced since 2006 years.

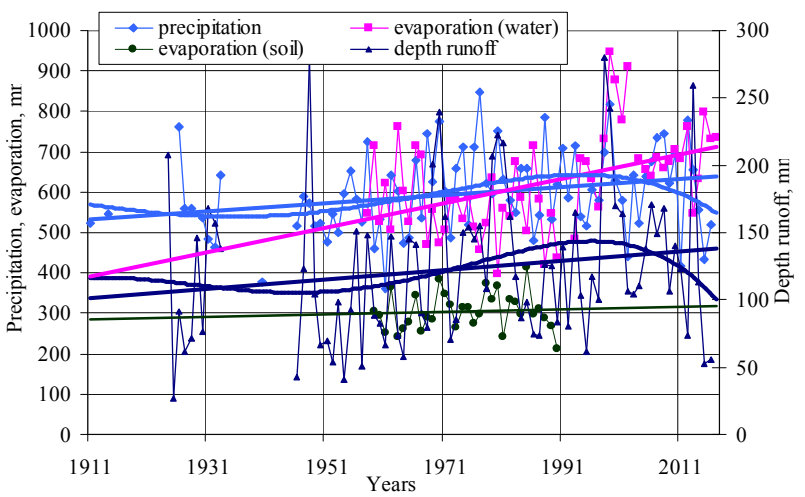

Figure 3. Historic trends of reduced of annual precipitation, evaporation from the water surface and soil by the Sarny weather station and the annual depth runoff on the hydrological post of the river Sluch - Sarny.

Soil moisture reserves in more powerful layers (0-50 the $0-100 \mathrm{~cm}$ ) show a greater range of variability over time than in less powerful layers $(0-10$ at $0-20 \mathrm{~cm})$.

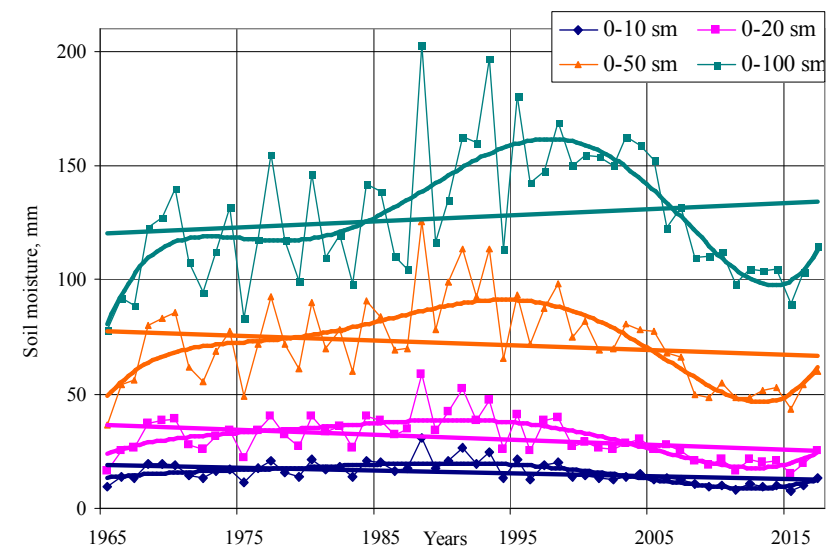

Figure 4. Historic trends of reduced soil moisture in layers 0-10, 0-20, 0-50 and $0-100 \mathrm{~cm}$ on the agrometstation of Sarny.

With the increase in evaporation from the water surface, the moisture reserves in the soil studied decrease. Greater dependence on precipitation shows water reserves in the $0-20 \mathrm{~cm}$ layer than $0-10$ or $0-50$ and $0-100 \mathrm{~cm}$, which is explained by the greater effect of air temperature on the top 
layer of soil $0-10 \mathrm{~cm}$, and greater variability of water reserves in more powerful layers of soil, which can also during separate periods tighten water from the chaplain edges of groundwater. As the air temperature increases, the water reserves in the soil decrease, and with the increasing capacity of the soil layer in question, this dependence weakens.

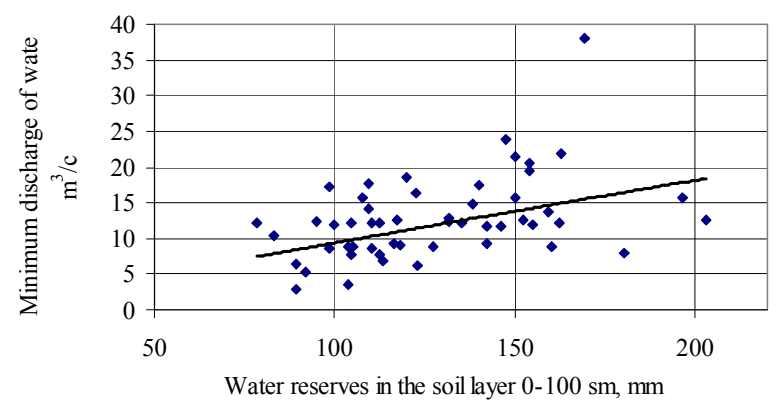

Figure 5. Dependence of the minimum water discharge for the year in the River Sluch - Sarny from the water reserves in the soil layer 0-100 cm.

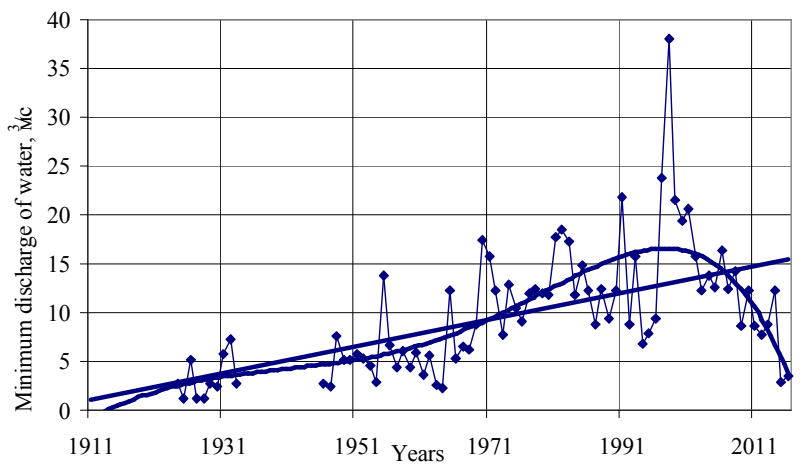

Figure 6. Change in the time of the minimum discharge of water for a year river Sluch-Sarny.

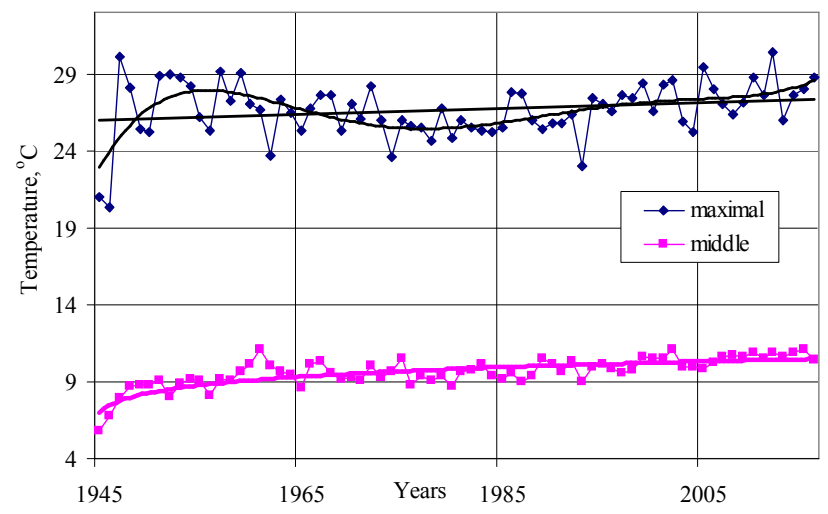

Figure 7. Historic trends of reduced of maximum and average water temperature for the year the river Sluch - Sarny.

With the increase in soil moisture content, the annual depth water runoff in the river increases, this dependence is more pronounced for more powerful layers of soil $(0-100 \mathrm{~cm})$. The dependence of water reserves in the soil with minimal water flow per year in the river is greater than with the annual runoff and it also increases with the increase in the capacity of the soil layer in question. With the increase in water reserves in the soil, the minimum water runoff for the year increases (Figure 5). The minimum water flow for the year in the perennial cut has also tended to decrease since 1998 (Figure 6), while the water temperature in the river (maximum and medium) at the hydrological post of Sarny is increasing (Figure 7). The paper [17] also states that the water temperature of small rivers depends on the share of unpaved food.

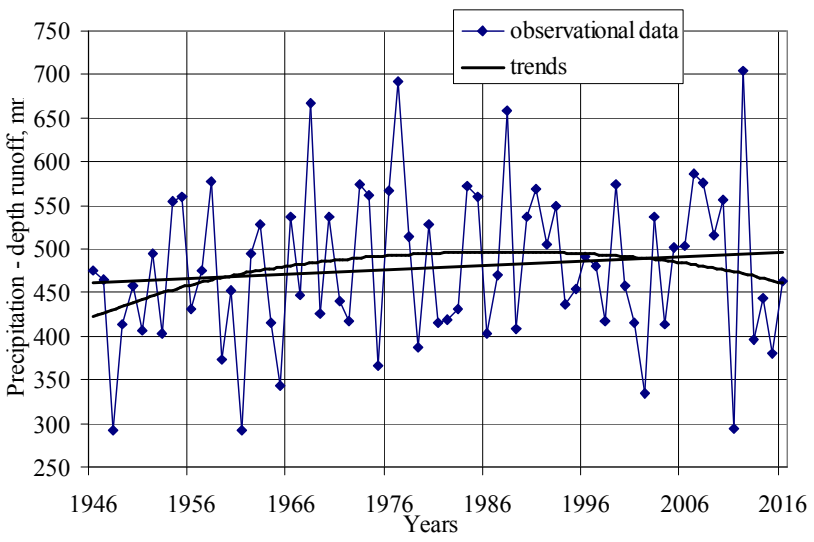

Figure 8. Change in time difference between precipitation and depth runoff on the River Sluch - Sarny.

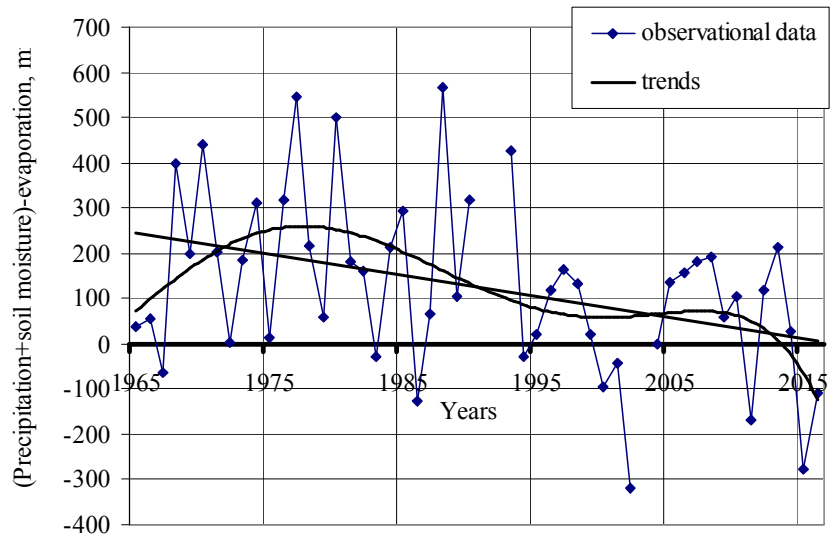

Figure 9. The change in time between the incoming part of the water balance (precipitation, water reserves in the soil layer $0-100 \mathrm{~cm}$ ) and evaporation from the water surface of the Sarny weather station.

Taking into account the above-mentioned changes in soil moisture, it can be considered that the reduction of river runoff at the hydrological post of the river Sluch - Sarny occurs due to the reduction of the ground inflow.

Analysis of the change in time difference between precipitation and runoff layer shows an upward trend (Figure 8 ), this difference characterizes the accumulation of water on the catchments [18]. While the difference between the positive component of the water balance (precipitation and water reserves in the meter layer of soil) and the consumable component (evaporation) shows a tendency to decrease over time, and in recent years we have even negative values (Figure 9). That is, evaporation exceeds the available inflow of 
moisture. The increase in precipitation, both globally and regionally, is also driven by an increase in evaporation. The higher the precipitation, the less evaporation from the water surface and the greater the evaporation from the soil. In cloudy weather, when precipitation falls, the influx of solar radiation decreases and evaporation from the water surface is also less, while evaporation from the soil is also determined by the heat of the soil thicker, so in cloudy weather here evaporation continues.

Studies of scientists in Belarus [19] on data up to 2000 have also shown trends in the growth of productive moisture reserves in the soil as a whole during the growing period, which is associated with a decrease in total evaporation and evaporation from the water surface. The decrease in total evaporation is due to the increase in atmospheric precipitation since the late 1990s and the decrease in wind speed in most of Belarus [19].

\section{Conclusions}

Studies have shown that the preservation of moisture in powerful soil layers $(0-100 \mathrm{~cm})$ contributes to the increase of water flow in rivers in the modern conditions of Polesya of Ukraine this will solve a number of problems with the provision of quality water resources to various industries and the population.

Moisture preservation in powerful soil-soil layers can be achieved by 1) restoration of marsh masses, 2) construction in the upper reaches of beams and beds of small constipation with seasonal delay of rain and melt water runoff (on the example of the Yunitsky Reserve - V. Dokuchayev experiments) with 3) mandatory carrying out of forest-forestry work for creation of favourable microclimate (reduction of wind speed, temperature, evaporation).

It should also be borne in mind that increased evaporation eventually contributes to increased air humidity, clouds and precipitation. The reduction of the surface component of the river flow of small rivers due to constipation should eventually not have a negative impact on the flow of larger rivers. Part of the runoff will pass to the internal and ground, which will reduce the water temperature in the rivers and thus eliminate a number of environmental problems caused by the increase in the water temperature in them.

The problem of reducing water in the Dnepr River can also be solved by regulating the discharge of water into the Black Sea by locks. The modern transgression of Black Sea levels allows regulating the flow of water to it without significant consequences.

The question of the impact of swamps on runoff is not new [20-22], there are opinions for recovery and against, but at present scientists are more inclined to believe that swamps do not increase interflow, that the impact of swamps on runoff is primarily related to the level of groundwater, which affects runoff [23-26]. As a matter of fact, the swamps have arisen in favour of the rise of groundwater levels. The lowest moisture capacity of peatlands is really high. However, it should be noted that this relationship is two-sided: peat deposits delay moisture and thus contribute to groundwater replenishment. Some sources note that the impact of swamps on runoff is not clear, but emphasize the local impact on the territory's microclimate [27]. Furthermore, the swamp studies cited compare rivers with different swamps or with partially runoff swamps, but neither with swamp-free rivers under the same conditions, i.e. it is not clear how much the runoff in swamp-free rivers has decreased compared to swamp-free rivers. But the fact of water accumulation and the influence on the microclimate of the area of marshland areas is undeniable.

With regard to reducing the flow of river waters into the Black Sea. The results of studies by several authors show that the impact of river water inflow on the rise of the Black Sea level is not confirmed, but the hypothesis of the impact on the growth of the Black Sea level of fluctuations in the level of the world ocean is confirmed [28, 29], and the existence of an oxygen zone and the absence of hydrogen sulphide in the upper layers of the Black Sea are also associated with the influx of Mediterranean Sea waters [30].

\section{References}

[1] Budnik S. V. (2017). Water Supply of Small Rivers and Environmental Management on Their Catchments. Materials of the VII International Scientific Conference: Environmental Management Problems and Environmental Situation in European Russia and Neighbouring Territories. Belgorode. 29-31. (in russian)

[2] Mokin V. B., Mokin B. I., Stashuk V. A., etc. (2009). The System of support of adoption of management decisions of Cari vnik of the water management organizations for DOP river basin "yat with use of geoinformation technologies. Vinnytsia universum Vinnytsia. 236. (in ukrainian)

[3] Stashuk V. A., Mokin V. B., Grebin V. V., Chunarev A. V. (2014). Scientific bases of rational use of water resources of Ukraine by the basin principle. Kherson: Grin D. S. 250. (in ukrainian)

[4] Bates, B. C., Z. W. Kundzewicz, S. Wu and J. P. Palutikof, Eds. (2008). Climate Change and Water. Technical Paper of the Intergovernmental Panel on Climate Change, IPCC Secretariat, Geneva. 210.

[5] Shtogrin I. (2020). "Dehydration": Ukraine has the lowest water level in rivers for the last 100 years.// Radio Liberty, April 23.

https://www.radiosvoboda.org/a/voda-vidstnist-opadiv-posuha -harchi/30572821.

$\mathrm{html}$ fbclid=IwAR0ar4ldSOQfVc6kRVfOxg0DD96R1Fyiaz NzTsKpmU2RrVo6zbXgLg54C0Y (in ukrainian).

[6] Budnik S. V. (2019). Spatio-Temporal Change of Atmospheric Precipitation on Territory of North-West of Ukraine. // Journal of Atmospheric Science Research. Vol 2. No 4. P. 4. DOI: https://doi.org/10.30564/jasr.v2i4.1564.

[7] Dolgov S. V., Koronkevich N. I. (2010). High-altitude and space-time analysis of the water balance of the European part of Russia. Water resources. Vol. 37. No. 2: 134-149. (in russian) 
[8] Arnold J. G, Srinivasan R., Muttiah R. S., Williams J. R. (1998) Large area hydrologic modeling and assessment. Part 1: model develooment. Journal of the american water resources association. V. 34. №1: 73-89.

[9] Hotchkiss R. H., Jorgensen S. F., Stone M., Fontaine T. A. (2000). Regulated river modeling for climate change impact assessment: the Missouri river. Journal of the american water resources association. V. 36. №2: 375-386.

[10] Kaczmarek Z. (1993.) Water balance model for climate impact analysis. Asta geophysica polonica. Vol. XLI. №4: 423-437.

[11] Surface water resources of the USSR. Main hydrological characteristics (for 1963-70 and the whole observation period). (1976). T. 6. Ukraine and Moldaviya. B. 2. Middle and lower podneprovie. L.: Hydrometeoisdate. 563. (in russian)

[12] Jamalov R. G., Frolova N. L., Krichevets G. N., Safronova T. I., Kireeva M. B., Igor M. I. (2012). Formation of modern resources of surface and underground waters of the European part of Russia. Water resources. V. 39. № 6: 571-589. (in russian)

[13] Robock, A., Vinnikov K. Y., Srinivasan G., Entin J. K., Hollinger S. E., Speranskaya N. A., Liu S., Namkhai A. (2000). The global soil moisture data bank. Bull. Amer. Meteor. Soc., 81: 1281-1299.

[14] Robock, A., Mu M., Vinnikov K., Trofimova I. V., Adamenko T I. (2005). Forty fi ve years of observed soil moisture in Ukraine: no summer desiccation (yet). Geophys. Res. Lett., 32, L03401, doi: 10.0129/2004GL021914.

[15] Fileccia T., Guadagni M., Hovhera V., Bernoux M. (2014). Ukraine: Soil fertility to strengthen climate resilience. Preliminary assessment of the potential benefits of conservation agriculture. - Rome: FAO. Report No. 9: 96.

[16] Kukharuk N. S., Smirnova L. G., Narodny A. G., Chandev Yu. G., Glazunov G. P. (2017). Dynamics of soil moisture of protected areas of forest steppe against the background of intra-century climatic variability. Scientific statements of Belgorodsky State. Un-ta, Ser. Natural sciences. № 25 (274). V. 41: 79-90. (in russian)

[17] Voskresenskiy K. P. (1951). Runoff of Rivers and Temporary Watercourses on the Territory of Forest Steppe and Steppe Zones of the European Part of the USSR. Works of the GGI.-Wp. 29 (83): 1146. (in russian)
[18] Zyryanova T. A., Zinchenko G. S., Besuglova N. N. (2007). Assessment of components of water balance of large Vasyugan marsh. Geography and natural resources. № 4: 68-74. (in russian)

[19] Volchek A. A. (2006.) Regularities of formation of elements of water balance of river catchments of Belarus in modern conditions. M. Autoreferat thesis for the degree of Doctor of Geographical Sciences. 42. (in russian)

[20] Oppokov E. V. (1909). On the Hydrological Role of Swamps. Agriculture and Forestry. № 9: 37-57. (in russian)

[21] Oppokov E. V. (1935). On the hydrological role of swamps and forests. Stenographer. Report by CNIILH, 20-23 Apr. 12-19. (in russian)

[22] Kuzmin G. F. (1993). Swamp and their use. St. scien. work. Issue. 70. SPb.: VNIITP. 140. (in russian)

[23] Volchek, A. A. Kasunova O. I. (2010). Minimal runoff of Rivers of Belarus. Brest: BrSU. 300. (in russian)

[24] Babikov B. V. (2012). Moisture consumption from runoffed forest marshes. News of higher education institutions. Forest magazine. №1: 14-17. (in russian)

[25] Babikov B. V. (2018). Hydrological role of swamps and water feeding of rivers. Forest Journal. № 5: 38-47. (in russian)

[26] Haranjevskaya Yu. A., Sinutkina A. A. (2017). Study of the role of marshes in the formation of the river flow of the basin of middle Obi. Geography and natural resources. № 3: 97-109. (in russian)

[27] Dmitrieva V. A. (2010). Hydrological Role of Lakes and Marshes of the Voronezh Region. VSU Gazette, Series: Geography. Geoecology. № 1: 98-102. (in russian)

[28] Goryachkin Yu. N., Ivanov V. A. (2006). Black Sea level: past, present and future. Sevastopol: NAS of Ukraine, Marine gidrofiz. Ins-t. 210. (in russian)

[29] Simonov V. G. A river runoff to the Black Sea. (2014). Sciences. works_UKRNIGMI, Vol. 266: 62-69. (in russian)

[30] Sustainability and Evolution of Oceanological Characteristics of the Black Sea Ecosystem. (2012). Under Ed. V. N. Eremeyeva, S. K. Konovalov; NAS of Ukraine, Marine Hydrophysical. In-t. - Sevastopol. 357. (in russian) 